Jurnal IImiah Dikdaya, 11(2), September 2021, 226-244

Publisher: Fakultas Keguruan dan IImu Pendidikan Universitas Batanghari Jambi ISSN 2088-5857(Print), ISSN 2580-7463 (Online)

DOI 10.33087/dikdaya.v11i1.1...

\title{
Pengaruh Kemandirian Belajar Dan Kemampuan Komunikasi Matematis Terhadap Hasil Belajar Matematisa Siswa Kelas XI IPA Di SMA Negeri 1 Kerinci
}

\author{
Zahara \\ Guru SMAN 1 Kerinci \\ Correspondence email: hasyimzahara66@gmail.com
}

\begin{abstract}
Abstrak. Penelitian ini memiliki tiga tujuan yaitu 1) untuk mengetahui pengaruh secara parsial kemandirian belajar terhadap hasil belajar matematika siswa kelas XI IPA di SMA Negeri 1 Kerinci; 2) untuk mengetahui pengaruh secara parsial kemampuan komunikasi matematis terhadap hasil belajar matematika siswa kelas XI IPA di SMA Negeri 1 Kerinci; dan 3) untuk mengetahui pengaruh secara simultan kemandirian belajar dan kemampuan komunikasi matematis terhadap hasil belajar matematika siswa kelas XI IPA di SMA Negeri 1 Kerinci. Penelitian ini menggunakan metode penelitian kuantitatif dengan dengan jenis pendekatan penelitian survey, yang menjadi populasinya adalah siswa kelas XI IPA di SMA Negeri 1 Kerinci yang berjumlah 75 siswa. Sampel dalam penelitian ini diambil dari jumlah populasi melalui teknik pengambilan sampel dengan menggunakan random sampling, Untuk menghitung sampel penelitian dari populasi tersebut, peneliti menggunakan pedoman penentuan sampel yang dikembangkan dari rumus Slovin dengan taraf tingkat kesalahan 10\% sehingga sampel dalam penelitian ini sebanyak 43 siswa. Instrumen yang digunakan dalam penelitian ini berupa angket kemandirian belajar (X1) dan kemampuan komunikasi matematis (X2) dengan skala likert untuk mengukurnya, serta hasil belajar matematika beardasarkan hasil belajar setelah proses belajar mengajar pada mata pelajaran matematika berakhir. Data dianalisis menggunakan analisis regresi linier berganda bantuan program SPSS for windows versi 25 . Hasil penelitian ini bahwa 1) terdapat pengaruh secara parsial kemandirian belajar terhadap hasil belajar matematika siswa kelas XI IPA SMA Negeri 1 Kerinci ditandai dengan nilai t hitung $>\mathrm{t}$ tabel $(3.290>1.683)$ dan siginifikansi $0,034<0,05 ; 2)$ terdapat pengaruh secara parsial kemampuan komunikasi matematis terhadap hasil belajar matematika siswa kelas XI IPA SMA Negeri 1 Kerinci ditandai dengan nilai $t$ hitung $>t$ tabel $(-2.375>1.683)$ dan siginifikansi $0,019<0,05 ; 3)$ tidak terdapat pengaruh secara simultan antara kemandirian belajar dan kemampuan komunikasi matematis terhadap hasil belajar matematika siswa kelas XI IPA SMA Negeri 1 Kerinci ditandai dengan nilai F hitung $<$ F tabel $1.842<$ 3.214) dan siginifikansi $0,089>0,05$. Besarnya pengaruh kemandirian belajar dan kemampuan komunikasi matematis terhadap hasil belajar matematika siswa kelas XI IPA SMA Negeri 1 Kerinci tergolong lemah yaitu sejumlah $21,4 \%$ dengan sisa $78,6 \%$ dipengaruhi oleh faktor lain di luar penelitian.
\end{abstract}

Kata Kunci: Kemandirian Belajar, Kemampuan Komunikasi Matematis, Hasil Belajar

\begin{abstract}
This study has three objectives, namely 1) to determine the partial effect of learning independence on mathematics learning outcomes for students of class XI science at SMA Negeri 1 Kerinci; 2) to determine the partial effect of mathematical communication skills on mathematics learning outcomes for students of class XI science at SMA Negeri 1 Kerinci; and 3) to determine the simultaneous effect of learning independence and mathematical communication skills on mathematics learning outcomes for students of class XI science at SMA Negeri 1 Kerinci. This study uses a quantitative research method with a survey research approach, the population is class XI science students at SMA Negeri 1 Kerinci totaling 75 students. The sample in this study was taken from the total population through a sampling technique using random sampling. To calculate the research sample from the population, the researcher used a sample determination guide developed from the Slovin formula with an error rate of $10 \%$ so that the sample in this study was 43 students. The instrument used in this study was a learning independence questionnaire (XI) and mathematical communication skills (X2) with a Likert scale to measure it, as well as mathematics learning outcomes based on learning outcomes after the teaching and learning process in mathematics subjects ended. The data were analyzed using multiple linear regression analysis with the help of SPSS for windows version 25. The results of this study are that 1) there is a partial effect of learning independence on mathematics learning outcomes for students of class XI IPA SMA Negeri 1 Kerinci marked by the value of $t$ count $>t$ table $(3,290>1,683)$ and a significance of $0.034<0.05 ; 2)$ there is a partial effect of mathematical communication skills on mathematics learning outcomes for students of class XI IPA SMA Negeri 1 Kerinci marked by the value of $t$ count $>t$ table $(-2.375>1.683)$ and a significance of $0.019<0.05 ; 3)$ there is no simultaneous influence between learning independence and mathematical communication skills on mathematics learning outcomes for students of class XI IPA SMA Negeri 1 Kerinci marked by the F count $<t$ table $1.842<3.214$ ) and a significance of $0.089>0.05$. The magnitude of the influence of learning independence and mathematical communication skills on mathematics learning outcomes for students of class XI IPA SMA Negeri 1 Kerinci is classified as weak, namely $21.4 \%$ with the remaining $78.6 \%$ influenced by other factors outside the study.
\end{abstract}

Keywords: Independent Learning, Mathematical Communication Ability, Learning Outcomes 
Zahara,Pengaruh Kemandirian Belajar Dan Kemampuan Komunikasi Matematis Terhadap Hasil Belajar Matematisa Siswa Kelas XI IPA di SMA Negeri 1 Kerinci

\section{PENDAHULUAN}

Matematika merupakan cabang ilmu eksakta sebagai ilmu yang menyeluruh secara universal dan banyak digunakan pada semua mata pelajaran sebagai kunci ilmu pengetahuan. Sifat objek matematika yang abstrak seharusnya menjadi tantangan untuk siswa mempelajari matematika, bukan siswa menjadi takut untuk mempelajarinya. Tidak sedikit siswa yang merasa takut dan sulit untuk mempelajari matematika. Sehingga banyak siswa yang merasa tidak bisa mengerjakan soal matematika sebelum mencoba mengerjakannya. Oleh karena itu, matematika perlu diajarkan pada semua jenjang pendidikan mulai dari sekolah dasar hingga perguruan tinggi untuk membekali siswa mengembangkan kemampuan dalam komunikasi tentang ide atau pemahaman masalah matematika dengan jelas. Tujuan pembelajaran matematika harus dipahami dengan baik oleh guru agar proses pembelajaran sesuai dengan apa yang diharapkan. Adapun tujuan dari mata pelajaran matematika menurut BSNP (2006) antara lain sebagai berikut:

(1) Memahami konsep matematika, menjelaskan keterkaitan antar konsep dan mengaplikasikan konsep atau algoritma, secara luwes, akurat, efisien, dan tepat, dalam pemecahan masalah;

(2) Menggunakan penalaran pada pola dan sifat, melakukan manipulasi matematika dalam membuat generalisasi, menyusun bukti, atau menjelaskan gagasan dan pernyataan matematika;

(3) Memecahkan masalah yang meliputi kemampuan memahami masalah, merancang model matematika, menyelesaikan model dan menafsirkan solusi yang diperoleh;

(4) Mengkomunikasikan gagasan dengan simbol, tabel, diagram, atau media lain untuk memperjelas keadaan atau masalah; dan

(5) Memiliki sikap menghargai kegunaan matematika dalam kehidupan, yaitu memiliki rasa ingin tahu, perhatian, dan minat dalam mempelajari matematika, serta sikap ulet dan percaya diri dalam pemecahan masalah. Tujuan pembelajaran matematika harus dipahami dengan baik oleh guru agar proses pembelajaran sesuai dengan apa yang diharapkan.

Salah satu kemampuan yang harus dipunyai siswa dalam pembelajaran matematika adalah kemampuan komunikasi, karena matematika merupakan bahasa yang berupa/melambangkan serangkaian makna dari pernyataan yang ingin kita sampaikan (Sulthani, 2014). Hal tersebut diperkuat oleh pernyataan Karnasih (2015) yang berpendapat bahwa komunikasi siswa tentang matematika dapat berhasil jika melibatkan guru dan siswa lain, yang mungkin memerlukan negosiasi makna dari symbol dan kata-kata pada beberapa tingkatan. Kemampuan komunikasi matematis menunjang kemampuan-kemampuan matematis yang lain. Pembelajaran matematika tidaklah semudah membalikan telapak tangan diperlukan ketekunan dan kemandirian belajar guna mencapai semua tujuan dari mata pelajaran matematika.

Banyak dampak yang ditimbulkan adanya pandemic covid 19 ini, salah satu diantaranya adalah proses pembelajaran yang dialami oleh para siswa pada jenjang pendidikan formal, yang semula proses pembelajaranya dilakukan secara tatap muka, namun adanya pandemic ini proses pembelajaran dilakukan secara daring. Adanya proses pembelajaran daring ini mau tidak mau ataupun suka tidak suka siswa dituntut untuk memiliki kemandirian dalam belajar sehingga tidak ketinggalan proses pembelajaran. Tuntutan terhadap kemandirian siswa untuk belajar sangat besar dan jika tidak tanggapi secara tepat bisa saja menimbulkan pengaruh yang tidak menguntungkan bagi perkembangan psikologis siswa di masa depan. Situasi dan kondisi tersebut terjadi karena adanya tuntutan untuk menjadi mandiri sebagai salah satu proses dan tugas dari perkembangan siswa. Siswa dituntut untuk menjadi mandiri agar dapat menyelesaikan tugas perkembangan selanjutnya. Agar siswa menjadi mandiri, maka siswa tersebut membutuhkan kesempatan, dukungan dan dorongan untuk dapat mencapai kemandirian atas diri mereka sendiri.

Berdasarkan hasil pengamatan pada siswa kelas XI IPA di SMA Negeri 1 Kerinci, selama musim pandemic ini karena pembelajaran dilakukan secara daring ditemukan beberapa permasalahan salah satunya tentang komunikasi belajar siswa yang rendah. Hal ini bisa dilihat dari selama proses pembelajaran daring siswa kurang mengungkapkan ketidakmengertian mereka atau ketidakpahaman mereka secara lisan, demikian juga dengan tulisan, dimana hasil dari pemberian tugas secara daring sebagian siswa menjawab tugas secara tulisan nilai masih tergolong rendah di bawah KKM. Kemampuan komunikasi rendah bisa 
Zahara,Pengaruh Kemandirian Belajar Dan Kemampuan Komunikasi Matematis Terhadap Hasil Belajar Matematisa Siswa Kelas XI IPA di SMA Negeri 1 Kerinci

terjadi karena kemandirian belajar siswa kurang dalam pembelajran matematika. Siswa hanya mengandalkan penjelasan dari guru yang memiliki waktu terbatas secara daring, dan tidak mau belajar mandiri dan bertanya pada guru materi yang belum mereka kuasai.

Permasalahan yang telah dipaparkan sebelumnya menjelaskan bahwa kemampuan komunikasi matematis dan kemandirian belajar dalam pembelajaran matematika merupakan dua komponen kompetensi yang amat sangat penting yang harus dikuasai siswa. Izzati (2012) mengungkapkan bahwa komunikasi matematis memerankan peranan penting dalam hal memahami matematikan maupun dalam hal menyampaikan matematika. Perlunya siswa memiliki kemandirian belajar agar siswa lebih mudah mengikuti pembelajaran matematika. Kemandirian belajar merupakan kesadaran diri, digerakkan oleh diri sendiri, kemampuan belajar untuk mencapai tujuannya (Brookfield, 2000). Kemandirian dalam belajar sangat diperlukan dalam mata pelajaran matematika dan mata pelajaran yang lain. Siswa yang memiliki kemandirian yang baik akan menemukan konsep dan cara belajar sendiri sehingga mampu memahami dan dapat menyelesaikan persoalan.

Guru berusaha mengembangkan belajar dengan cara siswa itu sendiri dan mereka berusaha menemukannya sendiri sehingga kemandirian belajar siswa dapat tumbuh dengan sendirinya. Sikap seorang gruru dalam pembelajaran matematika yang membuka peluang untuk siswa memperoleh gerak atau ruang kerja seluas-luasnya dalam waktu kerja dan caranya, ditandai dengan tidak menonjolkan peranan mengajar dalam kelas. Jadi kemandirian belajar adalah proses belajar yang dilakukan atas dorongan dari dalam siswa itu sendiri tanpa bergantung pada orang lain untuk mencapai kompetensi yang telah distandarkan guna mengatasi suatu masalah. Apabila siswa memiliki kemandirian belajar, maka siswa dapat mengerjakan tugas-tugas matematika tanpa bergantung orang lain dan mampu mengatasi masalah yang muncul pada dirinya. Sehingga dalam kemandirian belajar, seorang siswa harus proaktif serta tidak tergantung pada guru. Jika dilihat dari aspek kognitif maka dengan belajar secara mandiri akan didapat pemahaman konsep pengetahuan yang awet sehingga akan mempengaruhi pada pencapaian akademik siswa. Kondisi tersebut karena siswa sudah terbiasa menyelesaikan tugas yang didapat dengan usaha sendiri serta mencari referensi belajar yang telah tersedia.

Adanya kemandirian belajar secara tidak langsung akan membentuk kemampuan komunikasi dalam bentuk lisan dan tulisan. Permasalah yang telah dipaparkan tersebut, menentukan apa yang menjadi tujuan dari penelitian ini diantaranya : 1) untuk mengetahui pengaruh secara parsial kemandirian belajar terhadap hasil belajar matematika siswa kelas XI IPA di SMA Negeri 1 Kerinci; 2) untuk mengetahui pengaruh secara parsial kemampuan komunikasi matematis terhadap hasil belajar matematika siswa kelas XI IPA di SMA Negeri 1 Kerinci; dan 3) untuk mengetahui pengaruh secara simultan kemandirian belajar dan kemampuan komunikasi matematis terhadap hasil belajar matematika siswa kelas XI IPA di SMA Negeri 1 Kerinci.

\section{LANDASAN TEORI}

\section{Kemandirian Belajar}

Pendidikan sangat penting dalam menentukan kehidupan seseorang sebagai usaha untuk menuju perubahan menjadi lebih baik serta mampu memecahkan permaslahan yang menimpanya. Mewujudkan suatu perubahan dalam kehidupan seseorang bisa diwujudkan melalui proses belajar mengajar yang dilakukan oleh para siswa serta ilmu pengetahuan yang diperoleh baik di sekolah maupun diluar sekolah, karena di dalam proses belajar mengajar di sekolah peran guru sebagai pendidik, pembimbing serta pengajar yang mengajarkan hal- hal positif yang dapat membangun cara berfikir, bersikap, serta dapat meningkatkan kemandirian para siswa dalam menyelesaikan suatu permasalahan dan dalam menyelesaikan tugas- tugas sekolah. Kemandirian belajar salah satu aspek penting bagi setiap individu, karena dengan memiliki kemandirian menjadikan para siswa sadar akan kebutuhan belajar yang harus dilakukannya tanpa ada dorongan dari orang lain. Kemandirian dalam belajar dapat mewujudkan kehendak dan keinginan para siswa tanpa tergantung pada orang lain. 
Zahara,Pengaruh Kemandirian Belajar Dan Kemampuan Komunikasi Matematis Terhadap Hasil Belajar Matematisa Siswa Kelas XI IPA di SMA Negeri 1 Kerinci

Menurut pendapat Suhendri (2014) mendefinisikan kemandirian belajar sebagai kemampuan seorang siswa untuk berupaya secara mandiri dalam menggali informasi belajar dari sumber belajar selain guru. Hal senada juga diungkapkan Andriyani dan Supriani (2017) tentang kemandirian belajar itu merupakan suatu kebebasan untuk belajar dengan kemampuan siswa untuk mengatur sendiri kegiatan belajarnya, atas inisiatifnya sendiri serta secara bertanggung jawab, tanpa selalu tergantung pada orang lain. Pendapat yang sama juga telah diungkapkan Aisyah (2013) yang mendefinisikan kemandirian belajar sebagai suatu kemampuan para siswa untuk bertanggung jawab atas proses belajar dan berinisiatif dalam mengatasi masalah serta memenuhi kebutuhan untuk mencapai tujuan belajar.

Lebih lanjut Nurwahyuni (2013) mengungkapkan bahwa kemandirian belajar adalah kesanggupan siswa dalam menjalani kegiatan belajar dengan seorang diri tanpa tergantung kepada orang lain yang dilakukan dengan penuh kesabaran dan mengarah kepada suatu pencapaian tujuan yang diinginkan siswa tersebut. Kemandirian belajar juga dapat diartikan sebagai salah satu unsur terpenting yang harus dimiliki siswa dalam proses belajar mengajar, dan dapat memicu dalam memperbaiki prestasi dari proses belajar tersebut, karena menyangkut inisiatif siswa tersebut (Ali dan Asrori , 2012). Sedangkan Mulyaningsih (2014) mengungkapkan bahwa kemandirian belajar merupakan kegiatan belajar yang dilakukan siswa dengan sedikit atau sama sekali tanpa bantuan dari pihak luar.

Ada tiga aspek tentang kemandirian belajar menurut Tahar \& Enceng (2006) diantaranya yaitu pengelolaan belajar, tanggung jawab, dan pemanfaatan berbagai sumber belajar. Selain aspek kemandirian belajar juga mempunyai factor-faktor yang mempengaruhinya salah satunya yang diungkapkan oleh Djaali (2017) dimana menurutnya kemandirian belajar memiliki factor internal dan factor eksternal. Faktor-faktor internal yang mempengaruhi kemandirian belajar yaitu : Konsep Diri, motivasi, sikap, minat dan kebiasaan belajar. Sedangkan factor eksternal kemandirian belajar yaitu factor keluarga, factor sekolah, factor masyarakat, dan factor lingkungan sekitar. Menurut Slameto (2015) faktor-faktor yang mempengaruhi kemandirian belajar antara lain intelegensia, perhatian, minat, bakat, motif, kematangan, dan kesiapan. Adapun yang menjadi indicator untuk mengukur kemandirian belajar dalam penelitian ini menggunakan pendapat Mudjiman (2011) yaitu terdiri dari: 1) Percaya diri, 2) Aktif dalam belajar, 3) Disiplin dalam belajar, 4) Tanggungjawab dalam belajar.

\section{Kemampuan Komunikasi Matematis}

Matematika tidak hanya berkutat pada bilangan, akan tetapi tentang pola, kajian, hubungan, struktur, dan nilai kebenaran yang memiliki kekonsistenan di dalam sistemnya. Untuk mempelajari hal tersebut, maka diperlukan suatu komunikasi. Menurut Syaban (2008) kemampuan komunikasi dapat diartikan sebagai suatu peristiwa dialog atau hubungan yang terjadi di lingkungan kelas baik secara lisan ataupun tulisan. Masih menurut Syaban (2008) kemampuan komunikasi matematis secara lisan meliputi:

i. kemampuan siswa mengajukan pertanyaan,

ii. kemampuan siswa menjawab pertanyaan,

iii. kemampuan siswa menyampaikan pendapat,

iv. kemampuan siswa mempresentasikan hasil jawaban

Adapun komunikasi matematis tertulis menurut Syaban (2008) diantaranya meliputi: 1) merefleksikan benda-benda nyata, 2) membut model situasi atau persoalan menggunakan metode oral, tertulis, konkret, grafik, gambar atau aljabar, 3) menggunakan keahlian membaca, menulis dan menelaah, untuk menginterpretasikan dan menevaluasi ide-ide, symbol-simbol, istilah serta informasi matematika dan 4) merespon terhadap suatu pernyataan dalam bentuk argumen yang meyakinkan.

Menurut Hodiyanto (2017) menyatakan bahwa kemampuan komunikasi matematis merupakan suatu kemampuan siswa dalam menyampaikan ide matematika baik secara lisan maupun tulisan. Kemampuan komunikasi matematis peserta didik dapat dikembangkan melalui proses pembelajaran di sekolah, salah satunya adalah proses pembelajaran matematika. Prayitno, Suwarsono, dan Siswono (2013) mendefinisikan kemampuan komunikasi matematis sebagai suatu cara siswa untuk menyatakan dan menafsirkan gagasan-gagasan matematika secara lisan maupun tertulis, baik dalam bentuk gambar, tabel, 
Zahara,Pengaruh Kemandirian Belajar Dan Kemampuan Komunikasi Matematis Terhadap Hasil Belajar Matematisa Siswa Kelas XI IPA di SMA Negeri 1 Kerinci

diagram, rumus, ataupun demonstrasi. Selain beberapa definisi tentang komunikasi matematis, ada beberapa aspek yang mempengaruhinya menurut Baroody dalam Qohar (2011) diantaranya yaitu:

1) Representasi (representing), dimana Representasi dapat membantu siswa menjelaskan konsep atau ide, dan memudahkan anak mendapatkan strategi pemecahan;

2) Mendengar (listening), dimana mendengar merupakan aspek penting dalam suatu diskusi, pentingnya mendengar secara kritis juga dapat mendorong peserta didik memikirkan jawaban pertanyaan sambil mendengar.

3) Membaca (reading), merupakan aktivitas membaca teks secara aktif untuk menjawab pertanyaan yang telah disusun

4) Diskusi (discussing), dalam suatu diskusi peserta didik dapat mengungkapkan ide-idenya berkaitan dengan materi yang dipelajari

5) menulis (writing), dengan menulis peserta didik secara aktif membangun hubungan antara yang ia pelajari dengan apa yang sudah ia ketahui serta dapat membantu peserta didik dalam memahami materi yang ia pelajari.

Menurut Hasratuddin (2015) Kemampuan komunikasi matematis merupakan syarat untuk memecahkan masalah, artinya jika siswa tidak dapat berkomunikasi dengan baik memaknai permasalahan maupun konsep matematika, maka ia tidak dapat menyelesaikan masalah tersebut dengan baik. Kemampuan berkomunikasi sangatlah penting dalam semua disiplin ilmu dan dunia kerja, sehingga seseorang akan memiliki karakteristik kemampuan berkomunikasi, yang artinya bahwa seseorang harus dapat:(1) Membuat konsep, (2) Mengkomunikasikan mathematical thinking mereka secara koheren (tersusun secara logis) dan jelas kepada teman-temanya, guru, dan orang lain, (3) Menganalisis dan menilai mathematical thinking dan strategi yang dipakai orang lain, dan (4) Menggunakan bahasa matematika untuk mengekspresikan ide-ide matemtaika secara benar (Ramdani, 2012)

Untuk mengukur penilaian kemampuan komunikasi matematis menurut Kennedy et al (2015) dapat dilihat dari bebrapa indikator diantaranya meliputi:

(1) penggunaan bahasa matematika yang disajikan dalam bentuk lisan, tulisan ataupun visual,

(2) penggunaan representasi matematika yang disajikan dalam bentuk tulisan atau visual, dan

(3) penginterpretasian ide-ide matematika,menggunakan istilah atau notasi matematika dalam merepresentasikan ide-ide matematika, serta menggambarkan hubungan hubungan atau model matematika.

\section{Hasil Belajar}

Setelah kegiatan proses belajar mengajar berakhir, maka langkah selanjutnya akan dilakukan suatu evaluasi hasil belajar. Pada hakekatnya hasil belajar merujuk pada perubahan tingkah laku siswa sebagai hasil belajar yang mencakup bidang kognitif, afektif dan psikomotoris. Menurut Sudjana (2012) hasil belajar adalah kemampuan yang dimiliki siswa setelah menerima pengalaman belajar. Sesorang dapat dikatakan telah berhasil dalam belajar jika ia mampu menunjukkan adanya perubahan dalam dirinya (Wahidmurni, dkk. 2013). Perubahan-perubahan tersebut di antaranya dari segi kemampuan berpikirnya, keterampilannya, atau sikapnya terhadap suatu objek.

Lebih lanjut Hamalik (2012) mengemukakan tentang gambaran hasil belajar yang diperoleh dapat diukur melalui kemajuan yang diperoleh siswa setelah belajar dengan sungguh-sungguh. Hasil belajar tampak terjadinya perubahan tingkah laku pada diri siswa yang dapat diamati dan diukur melalui perubahan sikap dan keterampilan. Perubahan tersebut dapat diartikan terjadinya peningkatan dan pengembangan yang lebih baik dibandingkan dengan sebelumnya. Menurut Nasution et.al. (2012) ada beberapa prosedur tertulis yang dipakai untuk mengukur hasil belajar yang sifatnya kognitif dan afektif, sedangkan prosedur observasi dipakai untuk mengukur hasil belajar yang bersifat motorik.

Menurut Gagne (dalam Sudjana, 2012) mengembangkan kemampuan hasil belajar menjadi lima macam antara lain:

(1) hasil belajar intelektual merupakan hasil belajar terpenting dari sistem lingsikolastik; 
Zahara,Pengaruh Kemandirian Belajar Dan Kemampuan Komunikasi Matematis Terhadap Hasil Belajar Matematisa Siswa Kelas XI IPA di SMA Negeri 1 Kerinci

(2) strategi kognitif yaitu mengatur cara belajar dan berfikir seseorang dalam arti seluas-luasnya termaksuk kemampuan memecahkan masalah;

(3) sikap dan nilai, berhubungan dengan arah intensitas emosional dimiliki seseorang sebagaimana disimpulkan dari kecenderungan bertingkah laku terhadap orang dan kejadian;

(4) informasi verbal, pengetahuan dalam arti informasi dan fakta; dan

(5) keterampilan motorik yaitu kecakapan yang berfungsi untuk lingkungan hidup serta memprestasikan konsep dan lambing

\section{METODE PENELITIAN}

Metode penelitian yang digunakan dalam penelitian ini adalah metode kuantitatif dengan jenis pendekatan penelitian survey. Hal ini dipilih karena disesuaikan dengan tujuan penelitian ini yaitu untuk mengetahui pengaruh variabel bebas kemandirian belajar dan kemampuan komunikasi matematis terhadap hasil belajar matematisa siswa kelas XI di SMA Negeri 1 Kerinci. Adapun rancangan penelitian yang dapat digambarkan sebagai berikut:

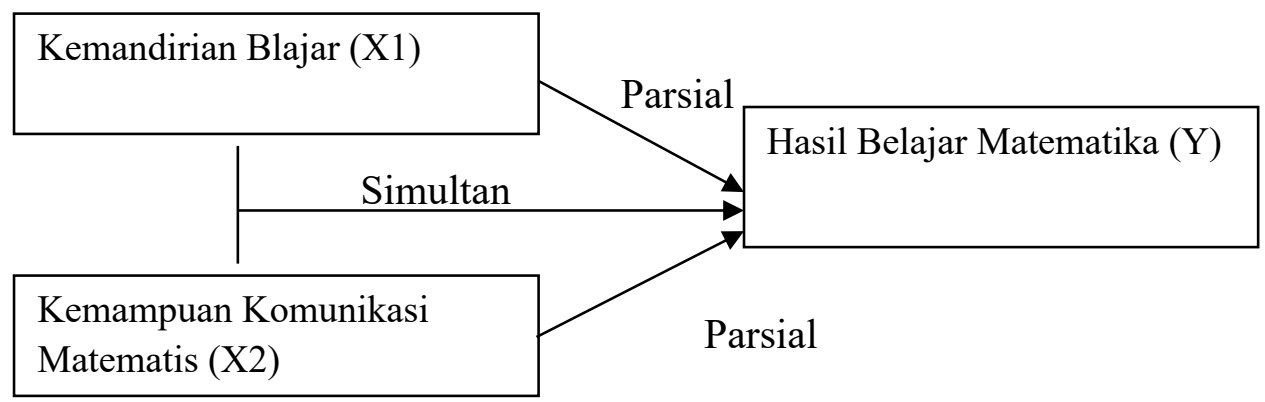

\section{Gambar 1 \\ Rancangan Penelitian}

Populasi yang digunakan dalam penelitian ini adalah seluruh siswa kelas XI IPA SMA Negeri 1 Kerinci. populasi adalah wilayah generalisasi yang terdiri atas, obyek/subjek yang mempunyai kuantitas \& karakteristik tertentu yang ditetapkan oleh peneliti untuk dipelajari dan kemudian ditarik kesimpulannya (Sugiyono, 2016). Jumlah seluruh populasi dalam penelitian ini dapat dilihat pada tabel berikut:

\section{Tabel 1}

Populasi Penelitian

\begin{tabular}{|l|l|c|}
\hline No & \multicolumn{1}{|c|}{ Siswa Kelas } & Jumlah \\
\hline 1 & XI IPA 1 & 25 \\
\hline 2 & XI IPA 2 & 25 \\
\hline 3 & XI IPA 3 & 25 \\
\hline & Jumlah & $\mathbf{7 5}$ \\
\hline
\end{tabular}

Telah diketahui dari tabel di atas bahwa jumlah populasi dalam penelitian ini sebanyak 75 siswa. Dari populasi tersebut akan diambel sampel penelitian dengan menggunakan teknik pengambilan sampel menggunakan random sampling untuk lebih mempermudah penelitian. Penarikan sampel dari populasi tersebut menggunakan pedoman penentuan sampel dengan rumus Slovin (Riyanto dan Andhita Hatmawan, 2020) pada taraf tingkat kesalahan $10 \%$ dari jumlah populasi 75 siswa, sehingga sampel dalam penelitian ini sebanyak 43 siswa. Penelitian ini membahas dua variable independen yaitu kemandirian belajar (X1) dan kemampuan komunikasi matematis (X2) serta satu variable dependent yaitu hasil belajar matematika (Y).

Untuk mengukur variable independent dengan menggunakan penyebaran angket yang disesuaikan dengan indicator dari masing-masing variable seperti variable independent kemandirian belajar (X1) menggunakan indicator yang dikemukakan Mudjiman (2011) yaitu Percaya diri, Aktif dalam belajar, 
Zahara,Pengaruh Kemandirian Belajar Dan Kemampuan Komunikasi Matematis Terhadap Hasil Belajar Matematisa Siswa Kelas XI IPA di SMA Negeri 1 Kerinci

Disiplin dalam belajar, dan Tanggungjawab dalam belajar. Variabel independent kemampuan komunikasi matematis (X2) menggunakan indicator yang dikemukakan Kennedy et al (2014) yaitu 1) penggunaan bahasa matematisa yang disajikan dalam bentuk lisan, tulisan ataupun visual; 2) penggunaan representasi matematisa yang disajikan dalam bentuk tulisan atau visual; 3) penginterpretasian ide-ide matematisa,menggunakan istilah atau notasi matematisa dalam merepresentasikan ide-ide matematisa, serta menggambarkan hubungan hubungan atau model matematisa.

Instrument angket tersebut bersifat tertutup berupa pernyataan atau pertanyaan dan disebarkan kepada siswa yang menjadi sampel dalam penelitian ini untuk memilih alternative jawaban yang telah disediakan dalam mengukur kemandirian belajar (X1) dan kemampuan komunikasi matematis (X2). Instrumen angket dari masing-masing variable independent tersebut menggunakan skala likert untuk mengukurnya, dan hasil belajar matematisa berdasarkan hasil belajar siswa selama mengikuti pelajaran matematisa satu semester. Selanjutnya akan dilakukan uji coba validitas dan reliabilitas dari angket tersebut sebanyak 30 siswa untuk mengumpulkan data. Setelah data tersebut dikatakn valid dan reliabel maka akan dilakukan uji analisis deskriptif, uji pra syarat statistic parametric (uji normalitas, uji homogenitas, uji linieritas), uji asumsi klasik (uji multikolinieritas dan uji heterosdeksitas), uji regresi linier berganda, dan uji hipotesis (uji t, Uji F, dan uji koefesien determinasi) dengan menggunakan bantuan SPSS for Windows versi 25 (Gozali, 2018).

\section{HASIL DAN PEMBAHASAN}

Berdasarkan hasil angket yang telah disebarkan kepada responden yang menjadi alat sebagai uji coba validitas sebanyak 30 siswa dapat diperoleh hasil dari masing-masing variable independent yakni kemandirian belajar (X1) dan kemampuan komunikasi matematis (X2) yang jumlah itemnya sama masingmasing 12 item pernyataan dapat dilihat pada tabel berikut:

\section{Tabel 2}

Uji Validitas

\begin{tabular}{|c|c|c|c|}
\hline $\begin{array}{c}\text { No } \\
\text { Item }\end{array}$ & $\begin{array}{l}\text { Corrected Item- } \\
\text { Total Correlation } \\
\text { Kemandirian } \\
\text { Belajar (X1) }\end{array}$ & $\begin{array}{c}\text { Corrected Item- } \\
\text { Total Correlation } \\
\text { Kemampuan } \\
\text { Komunikasi } \\
\text { Matematis (X2) } \\
\end{array}$ & $\begin{array}{l}\text { Sampel Uji Coba } 30 \\
\text { Siswa dengan } r \text { tabel }\end{array}$ \\
\hline Item 1 & .509 & .731 & \multirow{12}{*}{0,361} \\
\hline Item2 & .566 & .473 & \\
\hline Item3 & .829 & .536 & \\
\hline Item4 & .791 & .731 & \\
\hline Item5 & .406 & .473 & \\
\hline Item6 & .773 & .369 & \\
\hline Item7 & .829 & .731 & \\
\hline Item8 & .791 & .380 & \\
\hline Item9 & .379 & .502 & \\
\hline Item10 & .389 & .731 & \\
\hline Item 11 & .791 & .473 & \\
\hline Item 12 & .709 & .536 & \\
\hline
\end{tabular}

Tabel di atas menerangkan bahwa uji coba validitas variable kemandirian belajar (X1) dinyatakan valid karena hasil $r$ hitung $>\mathrm{r}$ tabel dengan sampel uji coba 30 siswa diperoleh $r$ tabel 0,361. Sedangkan untuk hasil uji uji coba validitas variable kemampuan komunikasi matematis (X2) dinyatakan valid karena hasil $r$ hitung $>r$ tabel sebesar 0,361 juga. Selanjutnya dilakukan uji reliabilitas dapat diketahui pada tabel berikut:

Tabel 3 
Zahara,Pengaruh Kemandirian Belajar Dan Kemampuan Komunikasi Matematis Terhadap Hasil Belajar Matematisa Siswa Kelas XI IPA di SMA Negeri 1 Kerinci

\section{Uji Reliabilitas}

Reliability Statistics (X1)
\begin{tabular}{|r|r|}
\hline $\begin{array}{c}\text { Cronbach's } \\
\text { Alpha }\end{array}$ & N of Items \\
\hline .868 & 12 \\
\hline
\end{tabular}

Reliability Statistics (X2)
\begin{tabular}{|r|r|}
\hline $\begin{array}{c}\text { Cronbach's } \\
\text { Alpha }\end{array}$ & N of Items \\
\hline .857 & 12 \\
\hline
\end{tabular}

Bila dilihat dari tabel uji reliabilitas di atas dapat diketahui bahwa variable kemandirian belajar (X1) dinyatakan reliable karena $r$ hitung uji reliabilitas sebesar $0.868>\mathrm{r}$ tabel dengan sampel uji coba 30 siswa diperoleh $r$ tabel sebesar 0,361. Sedangkan variable kemampuan komunikasi matematis (X2) dinyatakan reliable karena $r$ hitung uji reliabilitas sebesar $0.868>\mathrm{r}$ tabel sebesar 0,361 juga. Setalah dinyatakan valid dan reliable angket tersebut, langkah selanjutnya menyebarkan angket kembali kepada responden yang menjadi sampel dalam penelitian ini sebanyak 43 siswa. Setelah angket disebar dan diperoleh hasilnya dilakukanlah tabulasi data untuk pengujian selanjutnya. Langkah selanjutnya melakukan perhitungan uji analisis deskriptif yang dapat diketahui hasilnya pada tabel berikut:

\section{Tabel 4 \\ Uji Analisis Deskriptif}

Descriptive Statistics

\begin{tabular}{|l|r|r|r|r|r|}
\hline & $\mathrm{N}$ & Mean & \multicolumn{1}{|c|}{$\begin{array}{c}\text { Std. } \\
\text { Deviation }\end{array}$} & $\begin{array}{c}\text { Minimu } \\
\mathrm{m}\end{array}$ & $\begin{array}{c}\text { Maximu } \\
\mathrm{m}\end{array}$ \\
\hline $\begin{array}{l}\text { Kemandirian Belajar } \\
\text { (X1) }\end{array}$ & 43 & 50.49 & 7.494 & 31 & 60 \\
$\begin{array}{l}\text { Kemampuan } \\
\text { Komunikasi }\end{array}$ & 43 & 46.53 & 7.601 & 31 & 59 \\
$\begin{array}{l}\text { Matematis (X2) } \\
\text { Hasil Belajar (Y) }\end{array}$ & 43 & 75.49 & 6.584 & 60 & 90 \\
\hline
\end{tabular}

Tabel di atas menunjukan bahwa data yang disebarkan pada 43 siswa sebagai respondennya memilki nilai rata-rata, standar deviasi, nilai minimum dan maksimum bagi masing-masing variabel. Variabel kemandirian belajar (X1) memilki nilai mean sebesar 50,49, standar deviasi sebesar 7,494, nilai minimum sebesar 31 dan nilai maksimum 60. Untuk variabel kemampuan komunikasi matematis (X2) memilki nilai mean 46,53, standar deviasi sebesar 7,601 nilai minimum sebesar 31 dan nilai maksimum 59. Sedangkan untuk variabel hasil belajar matematisa (Y) memiliki nilai mean sebesar 75,49, standar deviasi sebesar 6,584, nilai minimum sebesar 60 dan nilai maksimum sebesar 90. Perhitungan data selanjutnya adalah untuk menguji data yang diperoleh dari penelitian tersebut berdistribusi normal atau tidak dapat dilihat pada tabel berikut:

\section{Tabel 5}

Uji Normalitas

\section{One-Sample Kolmogorov-Smirnov Test}


Zahara,Pengaruh Kemandirian Belajar Dan Kemampuan Komunikasi Matematis Terhadap Hasil Belajar Matematisa Siswa Kelas XI IPA di SMA Negeri 1 Kerinci

\begin{tabular}{|ll|r|r|r|}
\hline & & $\begin{array}{c}\text { Kemandiria } \\
\mathrm{n} \text { belajar } \\
\mathrm{X} 1\end{array}$ & $\begin{array}{c}\text { Kemampuan } \\
\text { Komunikasi } \\
\text { Matematis } \\
\text { X2 }\end{array}$ & $\begin{array}{c}\text { Hasil } \\
\text { Belajar } \\
\text { Matematik } \\
\text { a Y }\end{array}$ \\
\hline $\mathrm{N}$ & & 43 & 43 & 43 \\
Normal Parameters & Mean & 50.49 & 46.53 & 75.49 \\
& Std. & 7.494 & 7.601 & 6.584 \\
Most Extreme & Deviation & .120 & .082 & .102 \\
Differences & Absolute & .105 & .072 & .092 \\
& Positive & -.120 & -.082 & -.102 \\
Test Statistic & Negative & .120 & .082 & .102 \\
Asymp. Sig. (2-tailed) & & $.133^{\mathrm{c}}$ & $.200^{\mathrm{c}, \mathrm{d}}$ & $.200^{\mathrm{c}, \mathrm{d}}$ \\
\hline
\end{tabular}
a. Test distribution is Normal.
b. Calculated from data.
c. Lilliefors Significance Correction.
d. This is a lower bound of the true significance.

Hasil olahan data dapat dikatakan berdistribusi normal atau tidak dapat dilihat dari Asymp. Sig. (2tailed). Tabel di atas memiliki Asymp. Sig. (2-tailed) dari masing-masing variable independent yakni kemandirian belajar (X1) sebesar 0,133 > taraf signifikansi 5\% atau 0,05 maka dapat dikatakan bahwa data berdistribusi normal. Untuk variable independent kemampuan komunikasi matematis (X2) memiliki Asymp. Sig. (2-tailed) sebesar 0,200 > taraf signifikansi 5\% atau 0,05 maka dapat dikatakan bahwa data berdistribusi normal. Demikian juga untuk data hasil belajar matematika (Y) dimana Asymp. Sig. (2-tailed) diperoleh sebesar 0,200 > taraf signifikansi 5\% atau 0,05 maka dapat dikatakan data tersebut juga adalah berdistribusi normal. Apabila data telah berdistribusi normal langkah selanjutnya adalah menghitung homogenitas data untuk mengetahui variasi kelompok populasi homogeny atau tidak, dengan menggunakan uji Levene Statistic yang dapat dilihat pada tabel berikut:

\section{Tabel 6 Uji Homogenitas}

\begin{tabular}{|l|l|l|l|}
\hline No & \multicolumn{1}{|c|}{ Keterangan } & \multicolumn{1}{|c|}{$\begin{array}{c}\text { Levene } \\
\text { Statistic }\end{array}$} & \multicolumn{1}{|c|}{ Sig } \\
\hline 1 & Kemandirian Belajar * Hasil Belajar & 1.988 & 0,079 \\
\hline 2 & $\begin{array}{l}\text { Kemampuan Komunikasi Matematis } \\
* \text { Hasil Belajar }\end{array}$ & 2.568 & 0,148 \\
\hline
\end{tabular}

Dari tabel output di atas diketahui bahwa nilai levene statistic untuk mengetahui data tersebut homogeny atau tidak dari masing-masing hubungan variabel kemandirian belajar (X1) dengan hasil belajar matematika (Y) sebesar 1.988 dengan nilai sig 0,079 > 0,05, maka dapat dikatakan data tersebut adalah homogen. Selanjutnya untuk variabel kemampuan komunikasi matematis (X2) dengan hasil belajar matematika (Y) sebesar 2.568 dengan nilai sig $0,148>0,05$, maka dapat pula dikatakan data tersebut adalah homogen. Setelah data dari variabel tersebut homogen, maka dilakukanlah uji linieritas untuk mengetahui 
Zahara,Pengaruh Kemandirian Belajar Dan Kemampuan Komunikasi Matematis Terhadap Hasil Belajar Matematisa Siswa Kelas XI IPA di SMA Negeri 1 Kerinci

apakah data yang telah diperoleh selama penelitian, variabelnya memiliki hubungan yang linier atau tidak linier, dimana hasilnya dapat dilihat pada tabel berikut:

\section{Tabel 7}

Uji Linieritas

\begin{tabular}{|l|l|l|}
\hline No & \multicolumn{1}{|c|}{ Keterangan } & \multicolumn{1}{|c|}{$\begin{array}{c}\text { Sig. Deviation from } \\
\text { Linearity }\end{array}$} \\
\hline 1 & $\begin{array}{l}\text { Kemandirian Belajar * Hasil } \\
\text { Belajar }\end{array}$ & 0,158 \\
\hline 2 & $\begin{array}{l}\text { Kemampuan Komunikasi } \\
\text { Matematis * Hasil Belajar }\end{array}$ & 0,858 \\
\hline
\end{tabular}

Output hasil uji linieritas tersebut dilihat pada tabel uji anova, diketahui bahwa hubungan variabel kemandirian belajar (X1) dengan hasil belajar matematisa (Y) memilki hubungan yang linier. Hal tersebut dikarenakan nilai signifikansi dari deviation from linearity sebesar 0,158 $>$ taraf signifikansi 0,05 . Selanjutnya hubungan variabel kemampuan komunikasi matematis (X2) dengan hasil belajar matematika (Y) memilki hubungan yang linier, dilihat dari taraf signifikansi deviation from linearity sebesar 0,858 > taraf signifikansi 0,05 . Sehingga dapat disimpulkan bahwa data tersebut variabelnya memiliki hubungan yang linier. Setelah melakukan serangkaian uji prasyarat statistic (uji normalitas, homogenitas, dan linieritas), maka langkah selanjutnya data yang telah ditabulasikan dilakukan uji asumsi klasik yakni multikoliniearitas dan heterosdeksitas. Adapun hasil perhitungan dari uji multikolinearitas dapat dilihat pada tabel berikut:

\section{Tabel 8}

\section{Uji Multikolinearitas}

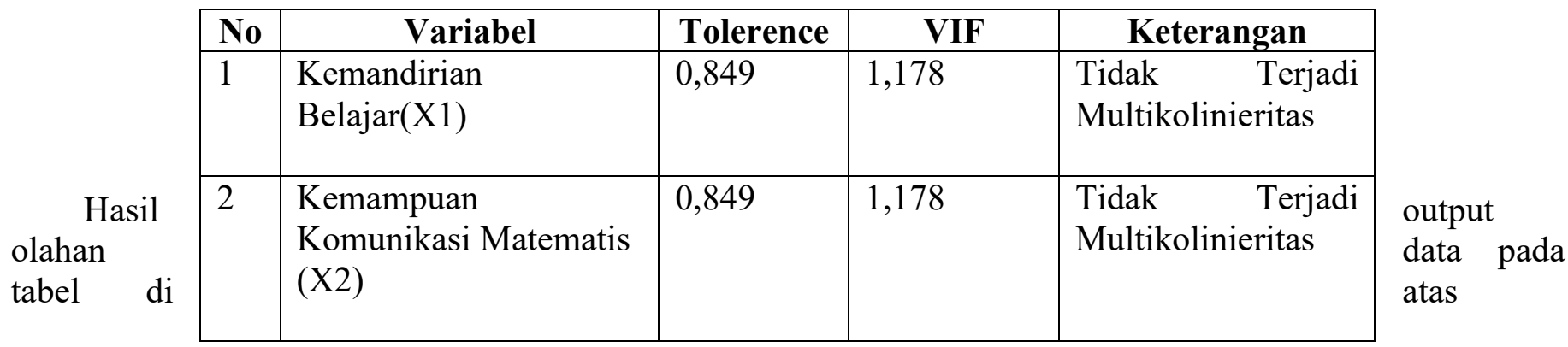

menunjukkan bahwa baik kemandirian belajar (X1) dan Kemampuan Komunikasi Matematis (X2) mempunyai nilai tolerance kurang dari 1, masing-masing mempunyai nilai tolerance 0,849 baik itu variable kemandirian belajar (X1) dan Kemampuan Komunikasi Matematis (X2). Sedangka nilai VIF yang dimemiliki masing-masing ariabel independent tersebut nilainya kurang dari 10 maka dapat dikatakan data tidak mengalami multikolinieritas. Setelah data tidak terjadi multikolinearitas, maka perhitungan selanjutnya adalah menghitung uji heterosdeksitas, dimana pengujian tersebut bertujuan untuk memeriksa apakah ada perbedaan yang tidak sama antara satu residu dan pengamatan lain atau adanya ketidaksamaan varian dari residual untuk semua pengamatan pada model regresi. Adapun hasil perhitunganya dapat dilihat pada tabel di bawah ini: 
Zahara,Pengaruh Kemandirian Belajar Dan Kemampuan Komunikasi Matematis Terhadap Hasil Belajar Matematisa Siswa Kelas XI IPA di SMA Negeri 1 Kerinci

\section{Tabel 9}

\section{Uji Heteroskedasitas}

\section{Coefficients $^{\mathrm{a}}$}

\begin{tabular}{|c|c|c|c|c|c|c|}
\hline \multirow{2}{*}{\multicolumn{2}{|c|}{ Model }} & \multicolumn{2}{|c|}{$\begin{array}{c}\text { Unstandardized } \\
\text { Coefficients }\end{array}$} & $\begin{array}{l}\text { Standardiz } \\
\text { ed } \\
\text { Coefficient } \\
\text { s } \\
\end{array}$ & \multirow[b]{2}{*}{$\mathrm{t}$} & \multirow[b]{2}{*}{ Sig. } \\
\hline & & B & $\begin{array}{l}\text { Std. } \\
\text { Error }\end{array}$ & Beta & & \\
\hline 1 & (Constant) & 12.604 & 4.534 & & 2.780 & .008 \\
\hline & $\begin{array}{l}\text { Kemandirian Belajar } \\
\text { X1 }\end{array}$ & -.195 & .084 & -.372 & -2.311 & .126 \\
\hline & Kemampuan & & & & & \\
\hline & $\begin{array}{l}\text { Komunikasi } \\
\text { Matematis X2 }\end{array}$ & .049 & .083 & .095 & .592 & .557 \\
\hline
\end{tabular}

a. Dependent Variable: Abs_RES

Dalam memaknai uji heterosdeksitas pada tabel di atas dengan menggunakan metode uji Glejser, maka cukup melihat "coefficients" melalui variable Abs_RES yang berperan sebagai variable dependentnya. Sementara itu, untuk melihat ada dan tidak terjadinya heteroskedasitas dapat dilhat dari nilai sig. pada tabel tersebut. Pada variabel kemandirian belajar (X1) nilai sig. sebesar 0,126 dan kemampuan komunikasi matematis (X2) memiliki nilai sig 0,557. Masing-masing nilai sig variable independent tersebut memiliki nilai lebih besar daripada 0,05. Maka, dapat disimpulkan bahwa data dari masing-masing variable independent tersebut tidak terjadi heteroskedastisitas. Setelah pengujian asumsi klasik memenuhi syarat untuk melakukan uji regresi linier berganda, maka langkah selanjutnya menghitung regresi linier berganda beserta uji hipotesisnya. Adapun hasil dari perhitungan analisis regresi linier berganda dapat dilihat pada tabel berikut:

Tabel 10

\section{Uji Regresi Linier Berganda}

\section{Coefficients $^{\mathrm{a}}$}

\begin{tabular}{|c|c|c|c|c|c|}
\hline \multirow[b]{2}{*}{ Model } & \multicolumn{2}{|c|}{$\begin{array}{c}\text { Unstandardized } \\
\text { Coefficients } \\
\end{array}$} & \multirow{2}{*}{$\begin{array}{c}\begin{array}{c}\text { Standardize } \\
\mathrm{d}\end{array} \\
\text { Coefficients } \\
\text { Beta }\end{array}$} & \multirow[b]{2}{*}{$\mathrm{t}$} & \multirow[b]{2}{*}{ Sig. } \\
\hline & $\mathrm{B}$ & Std. Error & & & \\
\hline $1 \quad$ (Constant) & $\begin{array}{r}68.40 \\
8\end{array}$ & 7.952 & & 8.602 & .000 \\
\hline $\begin{array}{l}\text { Kemandirian Belajar } \\
\text { X1 }\end{array}$ & .191 & .148 & .217 & 3.290 & .034 \\
\hline $\begin{array}{l}\text { Kemampuan } \\
\text { Komunikasi } \\
\text { Matematisa X2 }\end{array}$ & -.155 & .146 & -.163 & -2.375 & .019 \\
\hline
\end{tabular}

a.

Dependent Variable: 
Zahara,Pengaruh Kemandirian Belajar Dan Kemampuan Komunikasi Matematis Terhadap Hasil Belajar Matematisa Siswa Kelas XI IPA di SMA Negeri 1 Kerinci

Hasil Belajar Matematisa

Bentuk sebuah persamaan regresi linier berganda bisa dilihat dari koefisien $\beta$ yang dihasilkan dengan persamaan sebagai berikut: $\mathrm{Y}=68.408+0.191 \mathrm{X} 1-0.155 \mathrm{X} 2+$ e. Persamaan diatas dapat dijadikan acuan untuk menginterpretasikan masing-masing variable independent terhadap variable dependent sebagai berikut:

1. Koefisien Konstanta bernilai positif sebesar 68.408 artinya bahwa ketika kemandirian belajar tidak memperhatikan hasil belajar matematika siswa kelas XI IPA di SMA Negeri 1 Kerinci akan tetap memiliki hasil belajar matematika.

2. Koefisien kemandirian belajar bernilai positif sebesar 0.191 artinya setiap kenaikan kemandirian belajar yang dimiliki siswa kelas XI IPA di SMA Negeri 1 Kerinci meningkat, akan disertai dengan peningkatan hasil belajar matematika siswa. Sedangkan setiap penurunan kemandirian belajar yang dimiliki siswa kelas XI IPA di SMA Negeri 1 Kerinci menurun, akan disertai penurunan hasil belajar matematika siswa.

3. Koefisien kemampuan komunikasi matematis bernilai negative sebesar -0.155 artinya setiap usaha yang dilakukan siswa kelas XI IPA di SMA Negeri 1 Kerinci untuk melakukan komunikasi matematis menurun, akan disertai dengan penurunan hasil belajar matematika juga dan demikian pula sebaliknya.

Pada tabel 10 di atas juga dapat diketahui hasil uji t yang bertujuan untuk mengetahui pengaruh variabel independent secara parsial. Dari uji t tersebut dapat diketahui variable kemandirian belajar (X1) dengan hasil belajar matematika (Y). Untuk melihat nilai t tabel, maka terlebih dahulu harus menetapkan derajat kebebasan (dk). Keseluruhan sampel yang diteliti $(\mathrm{N})$ dalam penelitian ini ditentukan dengan rumus $\mathrm{dk}=\mathrm{n}-1$. Dalam penelitian ini, jumlah prediktor ada 2 yaitu kemandirian belajar (X1) dan total sampel yang digunakan adalah 43 siswa kelas XI IPA SMA Negeri 1 Kerinci maka dk $=42-2=41$ pada taraf signifikansi 5\%, maka diperoleh nilai $t$ tabel $=1,683$. Dimana nilai $t$ hitung yang dihasilkan pada variabel kemandirian belajar (X1) bernilai positif sebesar 3.290 dengan sig 0,034. Hasil tersebut mengindikasikan bahwa variabel kemandirian belajar (X1) memiliki pengaruh positif secara parsial dengan hasil belajar matematika (Y) yang dimilki siswa kelas XI IPA di SMA Negeri 1 Kerinci. Hal ini dikarenakan hasil perhitungan tersebut memiliki nilai t hitung sebesar 3.290 $>\mathrm{t}$ tabel sebesar 1.683 dengan taraf signifikansi sebesar 0,034 lebih kecil dari pada 0,05. Artinya variabel kemandirian belajar (X1) mempunyai pengaruh positif secara parsial dengan hasil belajar matematisa (Y). Sedangkan untuk variable kemampuan komunikasi matematis (X2) memiliki nilai negative sebesar -2.375 dengan sig 0,019 . Hasil tersebut mengindikasikan bahwa variabel kemampuan komunikasi matematis (X2) memiliki pengaruh negative secara parsial dengan hasil belajar matematika (Y) yang dimilki siswa kelas XI IPA di SMA Negeri 1 Kerinci. Hal ini dikarenakan hasil perhitungan tersebut memiliki nilai $\mathrm{t}$ hitung sebesar $-2.375>\mathrm{t}$ tabel sebesar 1.683 dengan taraf signifikansi sebesar 0,019 lebih kecil dari pada 0,05 artinya variabel kemandirian belajar (X1) mempunyai pengaruh secara parsial dengan hasil belajar matematika (Y).

Telah diketahui perhitungan secara parsial masing-masing variable independent, maka langkah selanjutnya melakukan perhitungan secara simultan dari keseluruhan variable independent yakni kemandirian belajar (X1) dan kemampuan komunikasi matematis (X2) terhadap variable dependent yakni hasil belajar matematika (Y). Berikut hasil dari perhitungan secara simultan dengan menggunakan uji $\mathrm{F}$ yang disajikan pada tabel di bawah ini:

Tabel 10

Uji F

\begin{tabular}{|c|c|c|c|c|c|}
\hline \multicolumn{6}{|c|}{ ANOVA $^{a}$} \\
\hline Model & $\begin{array}{l}\text { Sum of } \\
\text { Squares }\end{array}$ & df & $\begin{array}{l}\text { Mean } \\
\text { Square }\end{array}$ & $\mathrm{F}$ & Sig. \\
\hline $1 \quad$ Regression & 73.562 & 2 & 36.781 & 1.842 & $.089^{\mathrm{b}}$ \\
\hline
\end{tabular}


Zahara,Pengaruh Kemandirian Belajar Dan Kemampuan Komunikasi Matematis Terhadap Hasil Belajar Matematisa Siswa Kelas XI IPA di SMA Negeri 1 Kerinci

\begin{tabular}{|c|c|c|c|}
\hline Residual & 1747.183 & 40 & 43.680 \\
\hline Total & 1820.744 & 42 & \\
\hline
\end{tabular}

a. Dependent Variable: Y

b. Predictors: (Constant), X2, X1

Berdasarkan tabel di atas dapat diketahui bahwa nilai F hitung sebesar 1.842. Sebelum melihat nilai Ftabel, maka terlebih dahulu harus menentukan derajat kebebasan pembilang (df) dan derajat kebebasan penyebut $(\mathrm{db})$. Pada keseluruhan sampel yang diteliti $(\mathrm{N})$ dengan rumus $\mathrm{df}=\mathrm{m}$ (jumlah prediktor) dan $\mathrm{db}=$ $\mathrm{N}-\mathrm{m}-1$. Dalam penelitian ini, jumlah prediktor ada 2 (X1 dan X2) dan jumlah sampel yang digunakan adalah 58 mahasiswa, maka $\mathrm{df}=2 \mathrm{dan} \mathrm{db}=43-2-1=40$ pada taraf signifikansi $5 \%$. Maka ditemukan nilai $\mathrm{F}$ tabel $=3.214$ dengan taraf signifikansi sebesar 0,089 lebih besar dari pada 0,05 maka Ho ditolak. Sehingga dapat diartikan bahwa secara simultan kemandirian belajar (X1) dan kemampuan komunikasi matematis (X2), tidak mempunyai pengaruh signifikan secara simultan terhadap hasil belajar matematika (Y) siswa kelas XI IPA di SMA Negeri 1 Kerinci. Untuk mengetahui sumbangsih dari masing-masing variable independent secara bersamaan terhadap variable dependent dapat dilihat pada tabel berikut:

\section{Tabel 11}

\section{Koefesien Determinasi}

\begin{tabular}{|l|c|r|r|r|}
\hline Model & \multicolumn{1}{|c|}{ Model Summary } \\
\hline 1 & $.463^{\mathrm{a}}$ & .214 & $\begin{array}{c}\text { Adjusted R } \\
\text { Square }\end{array}$ & $\begin{array}{c}\text { Std. Error of } \\
\text { the Estimate }\end{array}$ \\
\hline
\end{tabular}

a. Predictors: (Constant), X2, X1

Dari tabel di atas menunjukkan Nilai R square sebesar 0,214 (51\%) yang dapat diintepretasikan bahwa variabel kemandirian belajar (X1) dan kemampuan komunikasi matematis (X2) menerangkan variasi variabel hasil belajar matematika (Y) siswa kelas XI IPA di SMA Negeri 1 Kerinci sebesar 21,4\% dan sisanya diperngaruhi variabel independen lainnya sebesar 78,6\%.

Berdasarkan hasil penelitian tersebut akan dilakukan pembahasan tentang hipotesis untuk menjawab tujuan dari penelitian ini, dimana hasil dari uji t yang diperoleh untuk variabel kemandirian belajar (X1) sebesar 3.290 dengan taraf nilai $\mathrm{Sig}=0,034$. Hasil perhitungan tersebut dapat ditarik suatu hipotesis diterima atau ditolak yaitu dengan melihat nilai $t$ dan taraf nilai signifikansinya. Adapun hipotesis yang diajukan dalam penelitian ini adalah sebagai berikut:

H0 : tidak ada pengaruh kemandirian belajar (X1) terhadap hasil belajar matematika (Y)

H1 : ada pengaruh kemandirian belajar (X1) terhadap hasil belajar matematika (Y)

Ketentuan dari hipotesis untuk menjawab tujuan pertama dari penelitian ini dapat diterima atau ditolak jika nilai $t$ hitung $>\mathrm{t}$ tabel dan taraf nilai Sig $<0,05$, maka $\mathrm{H} 0$ ditolak. Sedangkan jika nilai $\mathrm{t}$ hitung $<\mathrm{t}$ tabel dan taraf nilai Sig $>0,05$, maka H0 diterima. Perolehan nilai t hitung variabel independent kemandirian belajar (X1) sebesar $3.290>\mathrm{t}$ tabel $=1,683$ dan taraf nilai $\mathrm{Sig}=0,034<0,05$, sehingga dapat disimpulkan bahwa H0 ditolak. Artinya ada pengaruh kemandirian belajar (X) dengan hasil belajar matematika siswa kelas XI IPA SMA Negeri 1 Kerinci. Hasil penelitian ini sejalan dengan hasil penelitian Nasution dkk (2018) dengan judul "pengaruh kemandirian belajar terhadap hasil belajar siswa" yang menunjukan hasil bahwa kemandirian belajar memiliki pengaruh terhadap hasil belajar. Belajar mandiri bukan hanya dapat mengembangkan dirinya namun dapat mengembankan keterampilan cara tersendiri. Belajar mandiri bukan berarti belajar sendiri, belajar mandiri berupaya dengan segala yang dimilkinya untuk mengetahui pembelajaran, apabila mengalami kesulitas siswa bisa bertanya kepada guru tentang pembelajaran yang kurang dikuasai. Hal yang terpenting dalam proses dalam kemandirian belajar adalah keinginan dan keterampilan para siswa dalam proses belajar tanpa bantuan orang lain. Seperti yang diungkapkan Yamin 
Zahara,Pengaruh Kemandirian Belajar Dan Kemampuan Komunikasi Matematis Terhadap Hasil Belajar Matematisa Siswa Kelas XI IPA di SMA Negeri 1 Kerinci

(2013) kemandirian dalam belajar membutuhkan motivasi, keuletan, keseriusan, kedisiplinan, tanggung jawab, kemauan, dan keiginan tahuan untuk berkembang dan maju dalam mendapatkan pengetahuan. Dengan melakukan kemandirian belajar, siswa bisa berkesempatan untuk mencerna, memahami yang telah diberikan oleh guru dalam proses pembelajaran.

Adapun hipotesis yang diajukan dalam menjawab tujuan penelitian yang kedua dari penelitian ini adalah sebagai berikut:

H0 : tidak ada pengaruh kemampuan komunikasi matematis (X2) terhadap hasil belajar matematika (Y)

H1 : ada pengaruh kemampuan komunikasi matematis (X2) terhadap hasil belajar matematika

Ketentuan dari hipotesis untuk menjawab tujuan kedua dari penelitian ini dapat diterima atau ditolak jika nilai $\mathrm{t}$ hitung $>\mathrm{t}$ tabel dan taraf nilai Sig $<0,05$, maka $\mathrm{H0}$ ditolak. Sedangkan jika nilai $\mathrm{t}$ hitung $<\mathrm{t}$ tabel dan taraf nilai Sig $>0,05$, maka H0 diterima. Perolehan nilai t hitung variabel independent kemampuan komunikasi matematis $(\mathrm{X} 2)$ sebesar $-2.375>\mathrm{t}$ tabel $=1,683$ dan taraf nilai Sig $=0,019<0,05$, sehingga dapat disimpulkan bahwa H0 ditolak. Artinya ada pengaruh kemampuan komunikasi matematis (X2) terhadap hasil belajar matematika siswa kelas XI IPA SMA Negeri 1 Kerinci. Hasil penelitian ini senada dengan penelitian yang dilakukan Astuti (2015) dengan judul "peran kemampuan komunikasi matematisterhadap prestasi belajar matematika siswa" yang menunjukan hasil bahwa terdapat pengaruh positif dan signifikan kemampuan komunikasi matematika terhadap prestasi belajar matematika.

Adanya kemampuan komunikasi yang dipunyai siswa, maka siswa akan bisa memecahkan masalah matematika dengan menggunakan bahasa sendiri sebagai bentuk komunikasi dengan orang lain, terlebih lagi dengan penggunaan simbol dan kosakata matematika secara benar dan lancar merupakan bagian penting dalam pembelajaran matematika. Pada umumnya siswa enggan untuk mengadakan pembicaraan mengenai matematika kecuali untuk tujuan menyelesaikan tugas-tugas yang diberikan gurunya. Dalam perspektif ini pun, banyak siswa yang hanya mengikuti jalan pikiran atau bahkan meniru penyelesaian soal dari teman sekelas yang dianggap mampu atau pintar. Maka sebagi guru tugas yang utama untuk meningkatkan kemampuan komunikasi matematika yaitu dengan mengetahui dan manganalisa siswa yang kurang kreatif dan kurang mampu dalam menguasai pelajaran, sehingga guru dapat mengarahkan dan membimbing siswa ke arah yang lebih baik. Ada beberapa aspek yang dilakukan guru untuk meningkatkan kemampuan komunikasi matematik siswa menurut Tammi (2010) dalam menunjang hasil belajarnya yaitu:

1) Mengembangkan pemahaman dasar matematika siswa termasuk aturanaturan definisi matematika,

2) Membuat model dari suatu situasi melalui tulisan, bendabenda konkret, gambar, grafik, dan metode-metode aljabar,

3) Menyusun refleksi dan membuat klarifikasi tentang ide-ide matematika,

4) Menggunakan kemampuan memabaca, menyimak, dan mengamati untuk menginterpretasi dan mengevaluasi suatu ide matematika,

5) Mendiskusikan ide-ide, membuat konjektur, menyusun argument, merumuskan definisi, dan generalisasi, dan

6) Mengapresiasi nilai-nilai dari suatu notasi matematis termasuk aturan-aturannya dalam mengembangkan ide matematika.

Kemampuan komunikasi matematis sangatlah penting dalam pembelajaran matematika. Karena melalui komunikasi, siswa dapat mengorganisasi dan mengkonsolidasi berpikir matematisnya. Dan siswa dapat meng'explore' ideide matematikanya. Dalam pembelajaran matematika siswa dituntut untuk mengembangkan bahasa dan simbol matematika sehingga siswa dapat mengkomunikasikan secara lisan maupun tulisan, dan hal ini sudah pasti akan sangat berpengaruh terhadap hasil belajar matematikanya, karena dalam matematika untuk hasil belajarnya sangat berhubungan dengan kemampuan siswa dalam merepresentatifkan apa yang diketahui dan apa yang telah dipelajarinya ke dalam bahasa dan simbolik matematika. Selanjutnya hipotesa yang diajukan untuk menjawab tujuan penelitian yang ke tiga adalah sebagai berikut: 
Zahara,Pengaruh Kemandirian Belajar Dan Kemampuan Komunikasi Matematis Terhadap Hasil Belajar Matematisa Siswa Kelas XI IPA di SMA Negeri 1 Kerinci

H0 : tidak ada pengaruh secara simultan kemandirian belajar (X1) dan kemampuan komunikasi matematis (X2) terhadap hasil belajar matematika (Y)

matematis (X2)

H1 : ada pengaruh secara silmultan kemandirian belajar (X1) kemampuan komunikasi

terhadap hasil belajar matematika (Y)

Pengambilan keputusan hipotesis tersebut didasarkan dengan ketentuan penerimaan atau penolakan terjadi apabila Jika nilai $\mathrm{F}$ hitung $>\mathrm{F}$ tabel dan taraf nilai Sig $<0,05$, maka $\mathrm{H} 0$ ditolak. Jika nilai Fhitung $<$ F tabel dan taraf nilai Sig $>0,05$, maka H0 diterima. Karena nilai Fhitung $=1.842<\mathrm{F}$ tabel $=$ 3.214 dan taraf nilai Sig $=0,089>0,05$, sehingga dapat disimpulkan bahwa H0 ditolak. Artinya tidak ada pengaruh kemandirian belajar (X1) dan kemampuan komunikasi matematis (X2) terhadap hasil belajar matematika. Hasil penelitian ini bertolak belakang dengan penelitian Afiani (2016) dengan judul "Pengaruh Kemampuan Komunikasi Matematis Dan Kemandirian Belajar Terhadap Prestasi Belajar Matematika" yang menunjukan hasil bahwa terdapat pengaruh yang signifikan Kemampuan Komunikasi Matematis dan Kemandirian Belajar secara bersama-sama terhadap Prestasi Belajar Matematika. Melalui komunikasi dalam matematika, diharapkan dapat menolong guru memahami kemampuan siswa dalam menginterpretasikan dan mengekspresikan pemahamannya tentang konsep dan proses matematika yang mereka pelajari. Dalam proses pembelajaran matematika, menurut Susanto (2013) mengatakan bahwa "berkomunikasi matematis perlu ditumbuhkan, sebab salah satu fungsi pelajaran matematika yaitu sebagai cara mengkomunikasikan gagasan secara praktis, sistematis, dan efisien”.

\section{SIMPULAN}

Berdasarkan hasil penelitian yang telah dilakukan pada siswa kelas XI IPA SMA Negeri 1 Kerinci diperoleh hasil dan pembahasan yang dapat dipetik menjadi suatu kesimpulan bahwa 1) terdapat pengaruh secara parsial kemandirian belajar terhadap hasil belajar matematika siswa kelas XI IPA SMA Negeri 1 Kerinci ditandai dengan nilai $\mathrm{t}$ hitung $>\mathrm{t}$ tabel $(3.290>1.683)$ dan siginifikansi $0,034<0,05 ; 2)$ terdapat pengaruh secara parsial kemampuan komunikasi matematis terhadap hasil belajar matematika siswa kelas XI IPA SMA Negeri 1 Kerinci ditandai dengan nilai t hitung $>$ t tabel $(-2.375>1.683)$ dan siginifikansi $0,019<$ $0,05 ; 3)$ tidak terdapat pengaruh secara simultan antara kemandirian belajar dan kemampuan komunikasi matematis terhadap hasil belajar matematika siswa kelas XI IPA SMA Negeri 1 Kerinci ditandai dengan nilai $\mathrm{F}$ hitung $<\mathrm{F}$ tabel $1.842<3.214$ ) dan siginifikansi $0,089>0,05$. Besarnya pengaruh kemandirian belajar dan kemampuan komunikasi matematis terhadap hasil belajar matematika siswa kelas XI IPA SMA Negeri 1 Kerinci tergolong lemah yaitu sejumlah 21,4\% dengan sisa 78,6\% dipengaruhi oleh faktor lain di luar penelitian.

\section{DAFTAR PUSTAKA}

Aisyah, N. 2013. Pola Asuh Demokratis, Kepercayaan Diri Dan Kemandirian Mahasiswa baru. Persona. Jurnal Psikologi Indonesia, Mei Vol 2, No 2 halaman 108-121

Ali, M \& Asrori, M. 2012. Psikologi Remaja Perkembangan Peserta Didik. Jakarta: PT Bumi Aksara.

Andriyani, W. \& Suryani, N. 2017. Faktor-Faktor Yang Mempengaruhi Kesiapan Belajar Peserta Didik Kelas X Administrasi Perkantoran Di SMK Negeri 1 Slawi Tahun Pelajaran 2015/2016. 6(1). doi: http://journal.unnes.ac.id/sju/index.php/eeaj.

Astuti, Anggraini . 2017. Peran Kemampuan Komunikasi Matematika Terhadap Prestasi Belajar Matematika Siswa. Jurnal Formatif 2(2): 102-110 Issn: 2088-351x

Brookfield, S. D. 2000. Understanding and Facilitating Adult Learning. San fransisco: Josey-bass Publiser.

BSNP. 2006. Permendiknas RI No. 22 Tahun 2006 tentang Standar Isi untuk Satuan Pendidikan Dasar dan Menengah. Jakarta.

Djaali. 2017. Psikologi Pendidikan. Jakarta: PT Bumi Aksara

Ghozali, Imam. 2018. Aplikasi Analisis Multivariate dengan Program IBM SPSS 25. Semarang: Badan Penerbit Universitas Diponegoro: 
Zahara,Pengaruh Kemandirian Belajar Dan Kemampuan Komunikasi Matematis Terhadap Hasil Belajar Matematisa Siswa Kelas XI IPA di SMA Negeri 1 Kerinci

Hamalik, Oemar. 2012. Proses Belajar Mengajar. Jakarta: PT Bumi Aksara.

Hasratuddin. 2015. Mengapa Harus Belajar Matematika?. Medan: Perdana Publishing

Hodiyanto. 2017. Kemampuan Komunikasi Matematis Dalam Pembelajaran Matematika. AdMathEdu, 7(1), 9-18. $\quad$ https://www.neliti.com/publications/177556/kemampuan-komunikasimatematis-dalampembelajaran-matematika

Izzati, N. 2012. Peningkatan Kemampuan Komunikasi Matematis Dan Kemandirian Belajar Siswa Smp Melalui Pendekatan Pendidikan Matematika Realistik. Disertasi Tidak diterbitkan. Sekolah Pasca Sarjana UPI

Karnasih, Ida. 2015."Analisis Kesalahan Newman Pada Soal Cerita Matematis."Jurnal PARADIKMA FMIPA Unimed Medan 8(1): 37 - 51.

Kennedy, Adam S. Erin Horne, Kelcie Dolan, Cindy Herrera, Naomi Malutan, and Kathleen Noetzel. 2015. The Project Approach Meta-Project: Inquiry-Based Learning in Undergraduate Early Childhood Teacher Education. American Journal of Educational Research, vol. 3, no. 7: 907-917. doi: 10.12691/education-3-7-15.

Mudjiman, Haris. 2011. Belajar Mandiri. Surakarta: UNS PRESS.

Mulyaningsih, I. E. 2014. Pengaruh Interaksi Sosial Keluarga, Motivasi Belajar, dan Kemandirian Belajar Terhadap Prestasi Belajar. Jurnal Pendidikan dan Kebudayaan, 20, 443-445.

Nasution, Nurhidayah, Rizcka Fatya Rahayu, Siti Tami Maspupah Yazid, Destari Amalia. 2018. Pengaruh kemandirian belajar terhadap hasil belajar siswa. 2018. JURNAL PENDIDIKAN LUAR SEKOLAH Vol. 12, No. 1, hal 9-14

Nurwahyuni. 2013. Pengaruh Konsep Diri Siswa dan Pola Asuh Orangtua Terhadap Kemandirian Belajar Siswa SMP di Palu Sulawesi Tengah. Tri Sentral Jurnal Ilmu Pendidikan Vol. 2 Edisi 4 JuliDesember.

Prayitno, S., Suwarsono, St., \& Siswono, T.Y.E. 2013. Komunikasi Matematis Siswa SMP dalam Menyelesaikan Soal Matematika Berjenjang Ditinjau dari Perbedaan Gender. Prosiding Seminar Nasional Matematika dan Pendidikan Matematika FMIPA UNY. Yogyakarta

Qohar, A. 2011. Pengembangan Instrumen Komunikasi Matematis untuk Siswa SMP”. Makalah. Prosiding Seminar Nasional Pendidikan Matematika, FMIPA, Universitas Negeri Yogyakarta. Yogyakarta, 16 April 2011.

Ramdani, Yani. 2012. "Pengembangan Instrumen dan Bahan Ajar untuk Meningkatkan Kemampuan Komunikasi, Penalaran, dan Koneksi Matematis dalam Konsep Integral”. Jurnal Penelitian Pendidikan, Vol 13 No 1.

Riyanto, Slamet dan Hatmawan Aglis Andhita. 2020. Metode Riset Penelitian Kuantitatif Penelitian Di Bidang Manajemen, Teknik, Pendidikan Dan Eksperimen. Yogyakarta: Deepublish

Slameto. 2015. Belajar dan Faktor-faktor yang Memengaruhinya. Jakarta: Rineka Cipta

Sudjana, Nana. 2012. Penelitian Hasil Proses Belajar Mengajar. Bandung: Remaja Rosda Karya.

Suhendri, Huri. 2012. Pengaruh Kecerdasan Matematis Logis, Rasa Percaya Diri dan Kemandirian Belajar terhadap Hasil Belajar Mtematika pada Siswa Kelas X SMK di Kecamatan Jagakarsa Kota Jakarta Selatan. FKIP Pendidikan Matematika Universitas Indraprasta PGRI, ISBN : 978-979- 16353-8-7.

Sugiyono. 2016. Metode Penelitian Kuantitatif, Kualitatif dan R\&D. Bandung: PT Alfabet

Susanto, Ahmad. 2013. Teori Belajar dan Pembelajaran di Sekolah Dasar. Jakarta: Kencana Prenada Media Group.

Syaban, M. 2008. Menumbuhkembangkan Daya dan Disposisi Matematis Siswa SMA melalui Model Pembelajaran Investigasi. Jurnal Pendidikan dan Budaya Educare.

Tahar, Irzan dan Enceng. 2006. Hubungan Kemandirian Belajar dan Hasil Belajar Pada Pendidikan Jarak Jauh. Jurnal Pendidikan Terbuka dan Jarak Jauh, September 2006, Volume 7, Nomor 2, 91-101: Diterbitkan.

Tammi, Utami. 2017. Implementasi Model Pembelajaran Concept Attainment Terhadap Peningkatan Penguasaan Konsep Siswa SMA pada Materi Pencemaran Lingkungan. Skripsi Prodi Pendidikan Biologi, UNPAS: Tidak Diterbitkan 
Zahara,Pengaruh Kemandirian Belajar Dan Kemampuan Komunikasi Matematis Terhadap Hasil Belajar Matematisa Siswa Kelas XI IPA di SMA Negeri 1 Kerinci

Wahidmurni, dkk. 2013. Evaluasi Pembelajaran. Yogjakarta. Nuha Litera.

Yamin, M. 2013. Strategi dan Metode dalam Model Pembelajaran. Jakarta: Referensi (GP Press Group). 
Zahara,Pengaruh Kemandirian Belajar Dan Kemampuan Komunikasi Matematis Terhadap Hasil Belajar Matematisa Siswa Kelas XI IPA di SMA Negeri 1 Kerinci

\section{SIMPULAN}

Berdasarkan kepada permasalahan dan pertanyaan penelitian dan pembahasan yang telah dilakukan, maka dapat disimpulkan bahwa 1) Internal locus of control berpengaruh signifikan terhadap prestasi belajar mahasiswa pada Program Studi Pendidikan Ekonomi STKIP Nasional Padang Pariaman. Dimana ditunjukkan oleh nilai koefisien sebesar 0,000 Nilai koefisien ini signifikan karena nilai $t_{\text {hitung }} 4.313>t_{\text {tabel }}$ sebesar 1.697. 2) Pemberian punishment berpengaruh signifikan terhadap prestasi belajar mahasiswa pada Program Studi Pendidikan Ekonomi STKIP Nasional Padang Pariaman. Dimana ditunjukkan oleh nilai koefisien sebesar 0,004. Nilai koefisien ini signifikan karena nilai $t_{\text {hitung }} 3.127>t_{\text {tabel }}$ 1.697. 3) Gaya belajar visual berpengaruh signifikan terhadap prestasi belajar mahasiswa Program Studi Pendidikan Ekonomi STKIP Nasional Padang Pariama. Dimana ditunjukkan oleh nilai koefisien sebesar 0,015. Nilai koefisien ini signifikan karena nilai $t_{\text {hitung, }} 4,129>t_{\text {tabel }}$ sebesar 1.697. 4) internal locus of control,pemberian punishment, dan gaya belajar visual berpengaruh signifikan terhadap prestasi belajar mahasiswa pada Program Studi Pendidikan Ekonomi STKIP Nasional Padang Pariaman, artinya semakin baik internal locus of control, pemberian punishment, dan gaya belajar visual, maka prestasi belajar mahasiswa juga akan semakin baik. Hal tersebut bisa dilihat dari nilai $F_{\text {hitung }} 104.999>F_{\text {tabel }} 2,43$ dan nilai signifikan $0,000=0,05$. Hal ini berarti $\mathrm{H}_{0}$ ditolak dan $\mathrm{H}_{\mathrm{a}}$ diterima

Berdasarkan hasil penelitian dan kesimpulan yang telah penulis uraikan, maka untuk meningkatkan Prestasi belajar Mahasiswa Program Studi Pendidikan Ekonomi menjadi lebih baik untuk masa yang akan datang penulis menyarankan: 1) Untuk meningkatkan prestasi belajar mahasiswa ekonomi harus memperhatikan dan meningkatkan internal locus of control,pemberian punishment, kreatifitas belajar, dan gaya belajar visual, 2) Sebaiknya mahasiswa ekonomi meningkatkan internal locus of control karena dengan baiknya pengendalian diri seseorang idividu dan bekerja keras saat belajar, sehingga mendapatkan prestasi yang lebih baik lagi, 3) Buat dosen harus meningkatkan pemberian punisment kepada mahasiswa agar mahasiswa tersebut jera atau tidak maulagi untuk melanggar aturan yang telah dibuat. 4) Mahasiswa Program Studi Pendidikan Ekonomi agar memanfaatkan waktu dengan baik untuk menyelesaikan laporan atau tugas diperpustakaan dan menggumpulkan berbagai sumber bahan pelajaran untuk menambah kekurangan dari buku sumber. 5) Bagi peneliti selanjutnya dapat dijadikan rujukan dalam melakukan penelitian yang sejenis yang lebih mendalam di masa yang akan datang.

\section{DAFTAR PUSTAKA}

Aliasar, M. (2008). Bahan Ajar Pedagogik. Padang: UNP.

Hamalik. (2010). Proses Belajar Mengajar. Bandung: Bumi Aksara.

Irawan. (2000). Logika dan Prosedur Penelitian. Jakarta: STIA-LAN.

Kreitne, R \& Kinichi. (2001). Organizational Behavior, Fith Edition International Edition, MC Grawu Hill Companies, Inc.

Kompri. (2015). Motivasi Pembelajaran. Bandung. PT Remaja Rosdakarya. 
Zahara,Pengaruh Kemandirian Belajar Dan Kemampuan Komunikasi Matematis Terhadap Hasil Belajar Matematisa Siswa Kelas XI IPA di SMA Negeri 1 Kerinci

Kustini. (2005). Pengaruh Locus Of Control, Orintasi Tujuan Pembelajaran dan Lingkungan Kerja Terhadap Self Efficacy dan Tranfer Pelatihan Karywan PT, Telkom Kandetel Surabaya Timur. Studi Ilmu Penggembangan Sumber Daya Manusia, Thesis.Program Pasca Sarjana Universitas Ai.

Prasetya, F. D. (2012). Pengaruh Gaya Belajar Terhadap Prestasi Belajar Mata Diklat Listrik Otomotif Siswa Kelas XI Teknik Perbaikan Bodi Otomotif SMKN 2 Depok Sleman,.Jurnal. 1-208.

Robbins, P Stephen \& Timothy A Judge. (2008). Prilaku Organisasi. Jakarta: Salemba Empat. Sardiman, AM. (2011). Interaksi dan Motivasi Belajar Mengajar. Jakarta: PT. Rineka Cipta. Soemanto, Wasti. (2006). Psikologi Pendidikan. Jakarta: Rineka Cipta.

Sriwati. (2015). Kecerdasan Dan Gaya Belajar. Medan: Larispa Indonesia.

Sudjana. (2010). Dasar-Dasar Prosese Belajar Mengajar. Bandung: Rineka Cipta. 